\title{
Constraints Perceived by the Farmers in Adoption of IPM Practices in Cauliflower Cultivation in Jaipur District of Rajasthan, India
}

\author{
Sita Ram Bijarnia*, I. M. Khan, Ajit Kumar Ghoslya, \\ Vikas Kumar and Neelesh Raghuwanshi \\ Department of Extension Education, SKNAU, Jobner, India
}

*Corresponding author

\begin{tabular}{l} 
Ke y w o r d s \\
IPM, Cultural \\
Practices, \\
Knowledge, \\
Biocontrol \\
\hline Article Info \\
\hline $\begin{array}{l}\text { Accepted: } \\
\text { 20 February } 2020 \\
\text { Available Online: } \\
\text { 10 March } 2020\end{array}$ \\
\hline
\end{tabular}

Integrated Pest Management is one of such systematic approach which emphasizes not only the reduction in the use of pesticides and keeping below the level of pest causing economic injury but also it facilitates the use of cultural, mechanical, botanical, biological and chemical methods of control in an integrated manner and restores ecological balance for sustainable agriculture. The present study was conducted in the selected Chomu and Bassi tehsils of Jaipur district of Rajasthan. Four villages from each selected tehsil were taken on the basis of maximum area under cauliflower cultivation. Thus, total eight villages were selected for the study. For selection of respondents, comprehensive list of cauliflower growers was prepared and 15 respondents were selected on the basis of maximum area from each selected village. Thus, in all 120 farmers were included in the sample of the study. The major constraints perceived by cauliflower growers was lack of knowledge about pest's lifecycle and their infestation on cauliflower followed by Non-availability of Trichoderma at local markets, Lack of proper knowledge about insect-pests damaging stages" and Lack of knowledge about botanical pesticide.

\section{Introduction}

Cauliflower (Brassica oleracea var. botrytis) is one of the most important as well as popular winter vegetable crop, which is grown throughout the country. It is one of the oldest vegetables cultivated in the world believed to be since $2500 \mathrm{BC}$ by Greeks and
Romans. It is cultivated in India from the Mughal period. In India cauliflower is cultivated in 452.59-thousand hectare area with a total production of 8668.22 thousand million tonnes in 2017-18. The total area under cauliflower cultivation in Rajasthan is 10251 hectares with a total production of 51708 million tonnes in 2017-18. Vegetables 
play an important role in the maintenance of human health. These make diet nutritive and balanced. A balanced diet requires a proper quota of fresh vegetables.

\section{Materials and Methods}

The present study was conducted in Jaipur district of Rajasthan. This district consists of 16 tehsils. The district has 488 Gram Panchayats and 2400 Villages. Jaipur district was purposively selected for the present investigation due to having of the largest area under cauliflower crop cultivation in 20162017 in comparison to other districts of Rajasthan. From Jaipur district two tehsils namely Chomu and Bassi were selected on the basis of maximum area under cultivation of cauliflower. Four villages from each selected tehsil were taken on the basis of maximum area under cauliflower cultivation. Thus, total eight villages were selected for the present investigation. From the lists of prepared, 15 cauliflower growers were selected from each identified village. Thus, in all 120 farmers were included in the sample of the study. Data were collected through prestructured interview schedule.

The responses obtained from respondents were recorded on three- point continuum viz. most severe, severe and less severe which were assigned 3, 2 and 1 score respectively. The total score obtained by each respondent as well as for each statement mean per cent score was calculated. The respondents were divided into three categories on the basis of arbitrary method viz. low perception of the constraints, medium perception of the constraints and high perception of the constraints. Frequency and percentage of respondents in each category were calculated. Further to determine the intensity of different constraints, mean percent score for each constraint was worked out and ranked accordingly.

\section{Results and Discussion}

Constraints as perceived by the cauliflower growers in adoption of IPM practices in cauliflower cultivation

In the present context, the term constraint means all those barriers or obstacles, which were perceived by the cauliflower growers while adopting the IPM practices. It is needless to mention that the pace of adoption can be augmented by overcoming the perceived constraints. So, it was felt necessary to find out the constraints as perceived by the respondents in adoption of IPM practices in cauliflower cultivation. In the present context, the constraints perceived by the cauliflower growers in adoption of IPM were identified and same have been presented in subsequent tables.

\section{Distribution of respondents according to their level of perception of the constraints in adoption of IPM practices in cauliflower cultivation}

To get an overview of constraint level, the respondents were divided into three groups viz., (i) low level constraint perception (up to 33.33) (ii) medium level constraint perception (33.34 to 46.66) and high- level constraint perception (more than 46.66). The groups were formulated on the basis of arbitrary method. The results are presented in the Table 1.

The data in Table 1 reveal that out of 120 respondents, majority of respondents (56.67 per cent) fell in medium level of constraint perception group whereas, 31.67 per cent cauliflower growers were observed in the high level of constraint group and remaining 11.67 per cent respondents fell in the category of low level of constraint perception about Integrated Pest Management in cauliflower cultivation. 
Table.1 Distribution of respondents according to their level of perception of the constraints in adoption of IPM practices in cauliflower cultivation

\begin{tabular}{|c|c|c|c|c|c|c|c|}
\hline \multirow[t]{2}{*}{$\begin{array}{l}\text { S. } \\
\text { No. }\end{array}$} & \multirow[t]{2}{*}{$\begin{array}{l}\text { Constraint } \\
\text { (score) }\end{array}$} & \multicolumn{2}{|c|}{$\begin{array}{l}\text { Chomu Tehsil } \\
\qquad\left(n_{1}=60\right)\end{array}$} & \multicolumn{2}{|c|}{$\begin{array}{l}\text { Bassi Tehsil } \\
\qquad\left(\mathbf{n}_{2}=60\right)\end{array}$} & \multicolumn{2}{|c|}{$\begin{array}{c}\text { Total } \\
(n=120)\end{array}$} \\
\hline & & $\mathrm{F}$ & $\%$ & $\mathrm{~F}$ & $\%$ & $\mathrm{~F}$ & $\%$ \\
\hline 1. & Low (up to 33.33) & 6 & 10.00 & 8 & 13.33 & 14 & 11.67 \\
\hline 2. & $\begin{array}{l}\text { Medium ( } 33.34 \text { to } \\
46.66)\end{array}$ & 30 & 50.00 & 38 & 63.33 & 68 & 56.67 \\
\hline 3. & $\begin{array}{l}\text { High (more than } \\
\text { 46.66) }\end{array}$ & 24 & 40.00 & 14 & 23.33 & 38 & 31.67 \\
\hline & Total & 60 & 100.00 & 60 & 100.00 & 120 & 100.00 \\
\hline
\end{tabular}

$\mathrm{F}=$ Frequency, $\%=$ per cent

Table. 2 Constraints perceived by the cauliflower growers in adoption of IPM

\begin{tabular}{|c|c|c|c|c|c|c|c|}
\hline \multirow[t]{2}{*}{$\begin{array}{l}\text { S. } \\
\text { No. }\end{array}$} & \multirow[t]{2}{*}{ General Constraints } & \multicolumn{2}{|c|}{$\begin{array}{c}\text { Chomu } \\
\text { Tehsil }\left(\mathrm{n}_{1}=60\right)\end{array}$} & \multicolumn{2}{|c|}{$\begin{array}{c}\text { Bassi } \\
\text { Tehsil }\left(\mathbf{n}_{2}=60\right)\end{array}$} & \multicolumn{2}{|c|}{ Total $(n=120)$} \\
\hline & & MPS & Rank & MPS & Rank & MPS & Rank \\
\hline 1. & $\begin{array}{l}\text { Lack of knowledge about pests' life } \\
\text { cycle and their infestation } \\
\text { on cauliflower }\end{array}$ & 92.22 & I & 73.89 & VI & 83.06 & I \\
\hline 2. & $\begin{array}{l}\text { Lack of technical guidance regarding } \\
\text { ETL assessment }\end{array}$ & 74.44 & XI & 69.44 & XIV & 71.94 & XII \\
\hline 3. & $\begin{array}{l}\text { Improper monitoring of fields for } \\
\text { pest surveillance }\end{array}$ & 71.67 & XIV & 75.00 & IV & 73.33 & $\mathbf{X}$ \\
\hline 4. & $\begin{array}{l}\text { Non-availability of suitable } \\
\text { implement for field sanitation and } \\
\text { deep plugging }\end{array}$ & 73.89 & XII & 72.22 & IX & 73.06 & XI \\
\hline 5. & $\begin{array}{l}\text { Lack of knowledge } \\
\text { About crop rotation }\end{array}$ & 59.44 & XVIII & 62.78 & XVIII & 61.11 & XVIII \\
\hline 6. & $\begin{array}{l}\text { Lack of knowledge about improved } \\
\text { varieties of cauliflower }\end{array}$ & 52.78 & XX & 57.78 & XX & 55.28 & $\mathbf{X X}$ \\
\hline 7. & $\begin{array}{l}\text { Non- availability of high yielding } \\
\text { varieties of seed }\end{array}$ & 57.78 & XIX & 60.56 & XIX & 59.17 & XIX \\
\hline 8. & $\begin{array}{l}\text { High cost of high yielding varieties } \\
\text { of seed }\end{array}$ & 60.56 & XVII & 70.00 & XIII & 65.28 & XVII \\
\hline 9. & $\begin{array}{l}\text { Lack of technical guidance for seed } \\
\text { treatment }\end{array}$ & 73.33 & XIII & 68.33 & XVI & 70.83 & XIV \\
\hline 10. & $\begin{array}{l}\text { Non-availability of pesticide and } \\
\text { biofertilizers for seed } \\
\text { treatment }\end{array}$ & 66.67 & XV & 72.78 & VIII & 69.72 & XV \\
\hline 11. & $\begin{array}{l}\text { Supply of inferior } \\
\text { quality of biofertilizers }\end{array}$ & 77.22 & X & 71.67 & X & 74.44 & IX \\
\hline
\end{tabular}




\begin{tabular}{|c|c|c|c|c|c|c|c|}
\hline 12. & $\begin{array}{l}\text { Lack of knowledge } \\
\text { about intercropping }\end{array}$ & 65.56 & XVI & 71.11 & XI & 68.33 & XVI \\
\hline 13. & $\begin{array}{l}\text { Lack of knowledge about botanical } \\
\text { pesticide }\end{array}$ & 80.56 & V & 77.22 & II & 78.89 & IV \\
\hline 14. & $\begin{array}{l}\text { Non-availability of } \\
\text { neem cake at local level }\end{array}$ & 81.67 & III & 73.33 & VII & 77.50 & V \\
\hline 15. & $\begin{array}{l}\text { Lack of skill in } \\
\text { preparing NSKE solution }\end{array}$ & 80.00 & VI & 70.56 & XII & 75.28 & VII \\
\hline 16. & $\begin{array}{l}\text { Lack of knowledge about Bt } \\
\text { biopesticide }\end{array}$ & 81.11 & IV & 68.89 & $\mathrm{XV}$ & 75.00 & VIII \\
\hline 17. & $\begin{array}{l}\text { Lack of skill about biopesticide } \\
\text { application in cauliflower }\end{array}$ & 75.56 & VIII & 76.67 & III & 76.11 & VI \\
\hline 18. & $\begin{array}{l}\text { Non-availability of Trichoderma at } \\
\text { local market }\end{array}$ & 86.11 & II & 74.44 & V & 80.28 & II \\
\hline 19. & $\begin{array}{l}\text { Lack of knowledge about ETL for } \\
\text { using chemical pesticide }\end{array}$ & 75.00 & IX & 67.22 & XVII & 71.11 & XIII \\
\hline \multirow[t]{2}{*}{20.} & $\begin{array}{l}\text { Lack of proper knowledge about } \\
\text { insect- pests damaging stages }\end{array}$ & 78.33 & VII & 80.00 & I & 79.17 & III \\
\hline & Overall & 73.19 & & 70.69 & & 71.94 & \\
\hline
\end{tabular}

MPS $=$ Mean Per cent Score, $\mathrm{n}=$ Sample size

The analysis of the data in table 1further reveals that 50.00 per cent and 63.33 percent respondents were observed in medium constraint perception group in Chomu and Bassi Tehsils respectively, where as 40.00 per cent and 23.33 per cent respondents were observed in high constraint group in Chomu and Bassi Tehsils respectively. Only 10.00 and 13.33 per cent respondents were observed in low constraint group in Chomu and Bassi Tehsils respectively.

Aspect-wise constraints perceived by the cauliflower growers

A perusal of data in Table 2 reveals that the cauliflower growers of the study area most perceived the highest constraint about "Lack of knowledge about pests' life cycle and their infestation on cauliflower" (83.06 MPS) and was ranked first. The second most perceived constraint by the farmers was "Nonavailability of Trichoderma at local market" (80.28 MPS), was ranked second by the cauliflower growers.
The least perceived constraints by the farmers of the study area was "Lack of knowledge about improved varieties of cauliflower" (55.28 MPS) which was ranked last.

A perusal of data in Table 2 further reveals that the cauliflower growers of Chomu Tehsil most perceived the constraint "Lack of knowledge about pests' life cycle and their infestation on cauliflower" (92.22 MPS), whereas, the cauliflower growers of Bassi Tehsil perceived highest constraints about "Lack of proper knowledge about insectpests damaging stages" (80.00MPS).

The cauliflower growers of Chomu Tehsil perceived the second highest constraints about "Non-availability of Trichoderma at local market" (86.11 MPS), whereas, cauliflower growers of Bassi Tehsil had second highest constraints about "Lack of knowledge about botanical pesticide" (77.22 MPS). The cauliflower growers of both Chomu (52.78 MPS) and Bassi (57.78MPS) Tehsils low perceived the constraints regarding "Lack of 
knowledge about improved varieties of cauliflower".

As far as the extent of perception the constraints in adoption of IPM practices by the cauliflower growers of both the tehsils is covered the farmers of Chomu Tehsil had more constraints (73.19MPS) as compared to Bassi Tehsil (70.69MPS) regarding "Adoption of IPM". However, the extent of perception of the constraint in IPM practices by the cauliflower growers was found "Adoption of IPM" 71.94 per cent.

\section{References}

1. Agrawal, P.K., Singh, S.K. and Chouhan, S.R.K.S. 2014. Constraints in adoption of integrated pest management practices by the potato growers. Agriculture Update 9(1): 149-150.

2. Badhe, D.K., Patel, J.K., Patel, B.M. and Gulkari, K. 2012. Constraints faced by the farmers in bio-pesticides application. Greenfarming. 3(3):365-366.

3. Nidhi and Kalsariya, B. N. 2017. Constraints Faced by the Farmers in Adoption of IPM in Cauliflower Cultivation. International Journal of Botany and Research (IJBR) ISSN (P): 2277-4815; ISSN (E): 2319-4456.

4. Sable, B.D. and Kadam, R.P. 2013. Constraints faced by cotton growers in adoption of Integrated Pest Management. Journal of Agriculture Research and Technology, 38(3): 482-4.

\section{How to cite this article:}

Sita Ram Bijarnia, I. M. Khan, Ajit Kumar Ghoslya, Vikas Kumar and Neelesh Raghuwanshi. 2020. Constraints Perceived by the Farmers in Adoption of IPM Practices in Cauliflower Cultivation in Jaipur District of Rajasthan. Int.J.Curr.Microbiol.App.Sci. 9(03): 2656-2660. doi: https://doi.org/10.20546/ijcmas.2020.903.303 